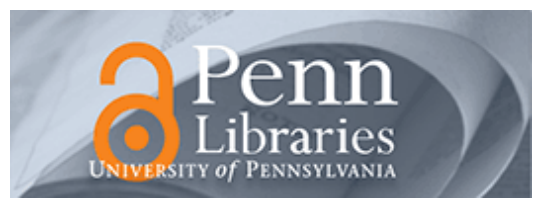

University of Pennsylvania ScholarlyCommons

November 2004

\title{
A New Species of Discinites (Noeggerathiales) Associated with a New Species of Yuania from the Lower Permian of Inner Mongolia, China
}

Jun Wang

Chinese Academy of Sciences

Hermann W. Pfefferkorn

University of Pennsylvania, hpfeffer@sas.upenn.edu

Zhuo Feng

Northwest University

Guanglong Shen

Northwest University

Follow this and additional works at: https://repository.upenn.edu/ees_papers

\section{Recommended Citation}

Wang, J., Pfefferkorn, H. W., Feng, Z., \& Shen, G. (2004). A New Species of Discinites (Noeggerathiales) Associated with a New Species of Yuania from the Lower Permian of Inner Mongolia, China . Retrieved from https://repository.upenn.edu/ees_papers/30

Copyright The University of Chicago Press. Reprinted from International Journal of Plant Sciences, Volume 165, Number 6, November 2004, pages 1107-1119.

Publisher URL: http://www.journals.uchicago.edu/IJPS/journal/

This paper is posted at ScholarlyCommons. https://repository.upenn.edu/ees_papers/30

For more information, please contact repository@pobox.upenn.edu. 


\title{
A New Species of Discinites (Noeggerathiales) Associated with a New Species of Yuania from the Lower Permian of Inner Mongolia, China
}

\author{
Abstract \\ A fructification Discinites baculiformis sp. nov. and the foliage Yuania wudensis sp. nov. are described \\ from the lower Permian Shanxi Formation of Wuda, Inner Mongolia, North China. Discinites baculiformis \\ sp. nov. is at least $31 \mathrm{~cm}$ long and $1.5-1.8 \mathrm{~cm}$ wide. It has more than 78 whorls of sporophylls, each with \\ ca. 85 sporangia on the adaxial side, a total of more than 6630 sporangia. The impression of the \\ sporophyll epidermis is preserved, and cells are visible. In situ trilete spores are detected. The new \\ species represents the longest strobilus with the largest number of whorls of sporophyll disks so far \\ known in the genus. Yuania wudensis sp. nov. has unbranched rachises, with alternate to subopposite \\ elongate ellipsoidal pinnae. Epidermal cells are rectangular, long, and narrow. The two new species might \\ represent the fructification and foliage of the same parent plant, since there is no other noeggerathialean \\ member in the taphonomic plant community. The association is comparable with the association of \\ Discinites and Russellites from the Permian of Texas.
}

\section{Keywords}

Discinites baculiformis sp. nov., Yuania wudensis sp. nov., Noeggerathiales, Permian, China.

\section{Comments}

Copyright The University of Chicago Press. Reprinted from International Journal of Plant Sciences, Volume 165, Number 6, November 2004, pages 1107-1119.

Publisher URL: http://www.journals.uchicago.edu/IJPS/journal/ 
Int. J. Plant Sci. 165(6):1107-1119. 2004.

(c) 2004 by The University of Chicago. All rights reserved.

$1058-5893 / 2004 / 16506-0018 \$ 15.00$

\title{
A NEW SPECIES OF DISCINITES (NOEGGERATHIALES) ASSOCIATED WITH A NEW SPECIES OF YUANIA FROM THE LOWER PERMIAN OF INNER MONGOLIA, CHINA
}

\author{
Jun Wang, ${ }^{1 * *}$ Hermann W. Pfefferkorn, † Zhuo Feng, \\ *Nanjing Institute of Geology and Palaeontology, Chinese Academy of Sciences, Nanjing 210008, China; tDepartment of \\ Earth and Environmental Science, University of Pennsylvania, Philadelphia, Pennsylvania 19104-6316, U.S.A.; \\ and ‡Department of Geology, Northwest University, Xi'an 710069, China
}

\begin{abstract}
A fructification Discinites baculiformis sp. nov. and the foliage Yuania wudensis sp. nov. are described from the lower Permian Shanxi Formation of Wuda, Inner Mongolia, North China. Discinites baculiformis sp. nov. is at least $31 \mathrm{~cm}$ long and $1.5-1.8 \mathrm{~cm}$ wide. It has more than 78 whorls of sporophylls, each with ca. 85 sporangia on the adaxial side, a total of more than 6630 sporangia. The impression of the sporophyll epidermis is preserved, and cells are visible. In situ trilete spores are detected. The new species represents the longest strobilus with the largest number of whorls of sporophyll disks so far known in the genus. Yuania wudensis sp. nov. has unbranched rachises, with alternate to subopposite elongate ellipsoidal pinnae. Epidermal cells are rectangular, long, and narrow. The two new species might represent the fructification and foliage of the same parent plant, since there is no other noeggerathialean member in the taphonomic plant community. The association is comparable with the association of Discinites and Russellites from the Permian of Texas.
\end{abstract}

Keywords: Discinites baculiformis sp. nov., Yuania wudensis sp. nov., Noeggerathiales, Permian, China.

\section{Introduction}

Discinites includes fossil bisporangiate strobili with sporangia arranged adaxially on a circular, fused sporophyll. The genus has been recorded from the Carboniferous of the Bohemian Massif, Czech Republic (Feistmantel 1880; Němejc 1937, 1941; Šimůnek and Bek 2003), the Carboniferous of the Netherlands (Hirmer and Guthörl 1940) and Germany (Remy and Remy 1956), the Carboniferous of Michigan (Arnold 1944, 1949) and lower Permian of Texas, U.S.A. (Mamay 1954), the Permian of Saudi Arabia (Hill and El-Khayal 1983), and the Carboniferous and Permian of China (Bohlin 1971; Gu and Zhi 1974; Wang 2000; Wang and Shen 2000).

Before the establishment of the family Discinitaceae in the order Noeggerathiales (Gao and Thomas 1994), Discinites had been assigned directly to the Noeggerathiales (Gothan and Weyland 1973; Taylor 1981), to the Noeggerathiineae (as a subdivision within the Filicales; Hirmer and Guthörl 1940), or to the order Discinitales in the Noeggerathiophyta (as a division; Zimmermann 1959; Boureau 1964). Palaeobotanists have always focused attention on Discinites as a wellrecognized noeggerathialean fructification in terms of the structure of the strobilus and the morphology of the sporophylls and in situ spores. However, this extinct plant group is insufficiently known, and its systematic position is still uncertain. Progress has been made in recent years in understanding the diversity and other properties of the group (Gao and Thomas 1994; Wang 2000; Wang and Shen 2000; Šimůnek and Bek 2003; Wang et. al. 2004; Bek and Šimůnek 2005).

\footnotetext{
1 Author for correspondence; telephone 86-25-83282227; fax 86-25-83357026; e-mail jun.wang@nigpas.ac.cn.
}

Manuscript received February 2004; revised manuscript received June 2004.
In this article, a new species of Discinites and a new species of Yuania are described on the basis of well-preserved specimens collected from the Wuda Coalfield, which is near the locality of the type specimen of Discinites sinensis (Wang 2000). Both new species display novel features: an unanticipated length in the Discinites strobilus and the morphology of the epidermal cells in Yuania pinnules, and consequently they expand our knowledge of Discinites and Yuania in both China and the Cathaysian flora.

\section{Material and Methods}

The fossils described here were collected from the early Permian Shanxi Formation of the Wuda coalfield of southwest Inner Mongolia, North China (fig. 1) at $39^{\circ} 28^{\prime} 53^{\prime \prime} \mathrm{N}$, $106^{\circ} 38^{\prime} 08^{\prime \prime} \mathrm{E}$ during a geological investigation to search for more materials of the petrified Discinites sinensis (Wang 2000). They are preserved in a black shale, and splitting of this matrix has produced both a compression and an impression counterpart. Some degagement of the specimens was necessary. This was successfully done with a medical syringe needle. Maceration of portions of sporophylls, sporangia, and laminae, unfortunately, yielded neither cuticles nor spores. Fragments of the strobilus and lamina were prepared for SEM observations. Samples were coated with gold using an Emscope sputter coater and examined with a JSM-6300/ LEO 1530VP scanning electron microscope. Some specimens were examined and photographed with a stereomicroscope (Leica DC300). All the figured specimens are deposited in the palaeobotanical collections of the Nanjing Institute of Geology and Palaeontology, Chinese Academy of Sciences, Nanjing, China (catalog numbers PB20252-20271). 


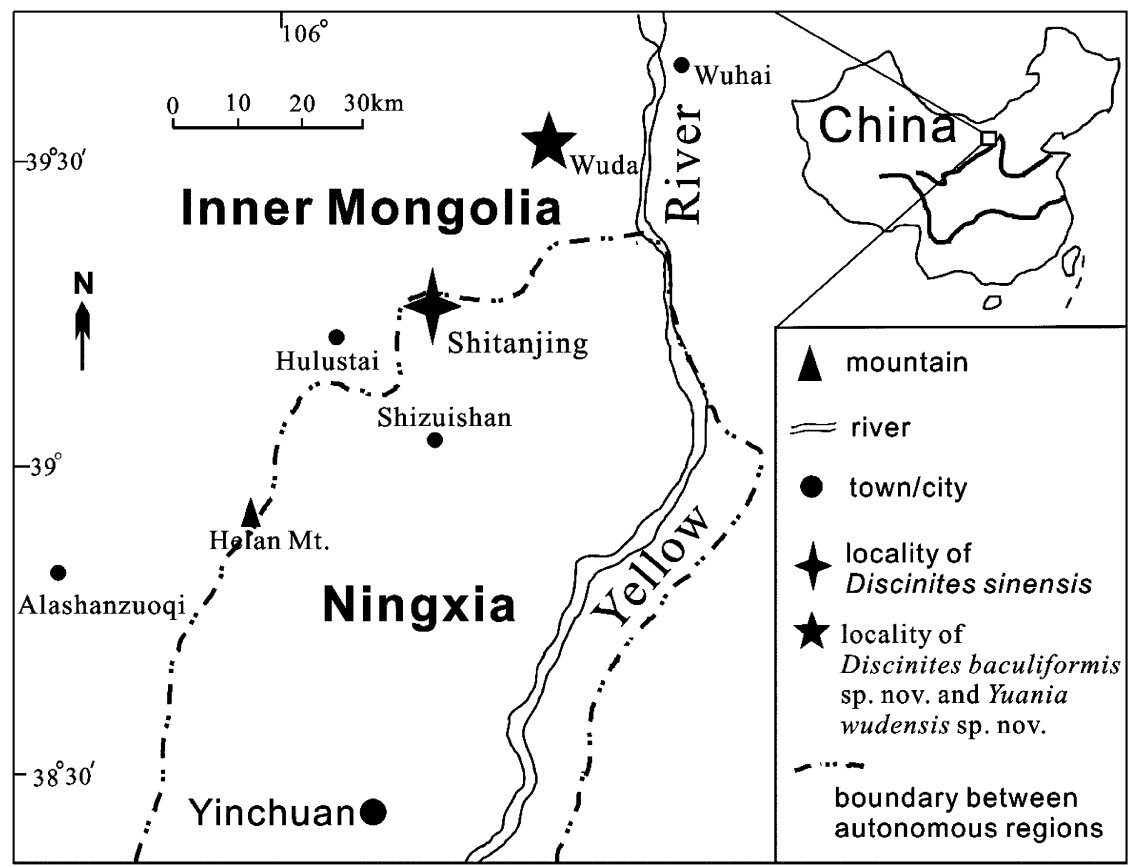

Fig. 1 Map showing the localities of Discinites baculiformis sp. nov. and Yuania wudensis sp. nov.

\section{Systematic Description}

Order—Noeggerathiales Němejc 1931

Family_Discinitaceae Gao and Thomas 1994

Genus_Discinites Feistmantel (1879) 1880

Type species—Discinites bohemicus Feistmantel 1880

Discinites baculiformis Wang, Pfefferkorn, Feng and Shen sp. nov.

Holotype. PB20252a, 20252b (fig. 2a, 2b).

Paratypes. PB20253-20258, 20268 (fig. 3a, 3c-3g).

Repository. Nanjing Institute of Geology and Palaeontology, Chinese Academy of Sciences, Nanjing 210008, China.

Type locality. Wuda, Inner Mongolia, China.

Stratigraphic position. Shanxi Formation.

Age. Early Permian (Asselian to Sakmarian).

Etymology. The specific name is derived from the Latin baculum (rod) implying that the strobilus is rod shaped, thin, and long as a whole.

Diagnosis. Strobilus more than $31 \mathrm{~cm}$ long, $1.5-2.0 \mathrm{~cm}$ in diameter, with a long pedicel; axis ca. $3.5-4.0 \mathrm{~mm}$ wide. Bases of sporophylls decurrent around the axis; proximal parts united to form a disk, with a right angle to the axis; distal parts upturned and parallel to the axis, deeply dissected into more than 50 teeth ca. $8-10 \mathrm{~mm}$ long and $2 \mathrm{~mm}$ wide at the base, with a single vein in the middle of the teeth. Sporangia elliptical, ca. $2.5-3.0 \mathrm{~mm}$ long and $0.7-1.0 \mathrm{~mm}$ wide, alternate and radiately arranged, forming four to five circles on the adaxial side of the disks. There are ca. 80-90 sporangia per disk. Epidermal cells of sporophyll are rectangular, 20-50 $\mu \mathrm{m}$ wide and 60-150 $\mu \mathrm{m}$ long, or polygonal,
$20 \times 40 \mu \mathrm{m}$ to $40 \times 85 \mu \mathrm{m}$ in size, with long axes parallel to the radius of the disk. Spores are in tetrads. The spores are ca. $50-80 \mu \mathrm{m}$ in diameter.

Description. From more than 50 specimens of Discinites baculiformis sp. nov., one was chosen as the holotype and seven as paratype specimens that best show the basal disk and apical teeth of the sporophylls and the position of the axis as well as the shape, size, and distribution of the sporangia.

The holotype specimen (fig. $2 a, 2 b$ ) consists of the part and counterpart of a single strobilus, compressed parallel to the axis. It is incomplete apically and basally. It is ca. $15 \mathrm{~mm}$ in diameter at the upper part and ca. $20 \mathrm{~mm}$ at the lower end and ca. $250 \mathrm{~mm}$ long. The axis is $3.5 \mathrm{~mm}$ wide in the middle. The disks of sporophylls are ca. 3-4 mm apart vertically, with slightly wider separation in the lower part than the upper part. There are at least 60 disks of sporophylls recognizable on the preserved part of the strobilus. The middle upper part, i.e., about three-fourths of the specimen from the base upward, is laterally broken on the holotype (fig. $2 a$, frame), but this part of the strobilus is well preserved on the counterpart (fig. $2 b$, frame; fig. $2 c$ ), showing that these two parts form a continuous strobilus. The characteristic sporangial arrangement of Discinites is well demonstrated at the uppermost and the lower part of the holotype (fig. $2 a, 2 d$ ). The connection of the sporophyll disk with the axis is visible at the middle lower part of the holotype (fig. $2 a$, upper left arrowhead; fig. $2 d$ ) and some other specimens (fig. $3 a, 3 f$ ), showing that the very base of sporophyll is slightly decurrent.

The distal parts of the sporophylls are usually not well preserved. After the matrix (fig. $2 a$, lower left arrowhead) was removed, the upturned distal parts of sporophylls were 
clearly visible (fig. $3 b$ ). They are upturned at a right angle, extend upward to overlap the next whorl of sporophylls, and are parallel with the axis of the strobilus. They are obviously longer than the spaces between the disks. Occasionally, in cases where the fracture pathway of the strobilus passes longitudinally through the edge of the sporophyll disk (fig. 3e), the apical teeth of sporophylls are clearly visible. The periphery of a fragmentary disk forms an arc, where the number of teeth can be counted. Judging from the width of such arcs in relation to the circumference of the disk, there are ca. 50 teeth per disk. A good example is shown in figure $3 c$, where there are ca. 12 teeth recognizable on the well-preserved quarter part of the disk of sporphylls. There is a single vein in the middle of the apical teeth of the sporophylls, the same length as the teeth themselves.

The specimen in figure $3 d$ clearly shows the articulate sporophyll disks. The apical teeth of sporophylls are not preserved. The specimen in figure $3 g$ demonstrates the basal pedicel of the strobilus. The strobilus shown in figure $6 b$ (to the left) is $310 \mathrm{~mm}$ long, excluding the unpreserved base and apex, $18 \mathrm{~mm}$ wide at the lower part, and $15 \mathrm{~mm}$ wide at the upper part. The distance between two whorls of sporophyll disk is ca. $4 \mathrm{~mm}$ on average, and consequently ca. 78 whorls of disks are preserved in total.

Epidermal cells of the sporophylls vary in shape along with their position. As shown in figure $4 c, 4 e$, and $4 j$, those besides the sporangia are long and narrow, usually rectangular, with the ends pointed, and with the longer sides four to seven times the length of the short sides. They are normally $80-140 \mu \mathrm{m}$ long and $20-35 \mu \mathrm{m}$ wide. Cells are arranged with their longer axes parallel to the radial direction of the sporophyll disk (fig. 4o). The cells on the area at the point of attachment of a sporangium (fig. $4 j, 4 m$ ) are short and wide, varying remarkably in size and shape. They may range from $20 \times 40 \mu \mathrm{m}$ to $40 \times 85 \mu \mathrm{m}$ in size. They are basically irregularly hexagonal in shape but occasionally more irregular. Neither ornamentations nor thickenings occur on the periclinal or anticlinal walls (fig. 4h-4o). Stomata have not been detected on the surface of sporophylls with certainty. The more than $150-\mathrm{mm}^{2}$ area of the surface of the sporophylls was examined for stomata, and only two (fig. $4 h, 4 i$ ) could be found. However, these could also be artifacts of preservation, because numerous places can be observed where grains of extraneous matter have been adpressed to the surface.

The sporangia are alternately and radiately arranged, with an inclination outward from the axis (fig. $2 a, 2 d$; fig. $4 a, 4 b$ ). They are basically elliptical, measuring $2.5-3.0 \mathrm{~mm}$ in length and $0.7-1.0 \mathrm{~mm}$ in diameter. They vary more or less in form and size due to various degrees of compression. They may be slightly bigger as a result of a high degree of compression, and this might be the case for those sporangia close to the axis of the strobilus (fig. $2 d$, lower black arrowhead; fig. $4 a$, lower arrowhead), or slightly smaller due to minimal compression. This might be the case of those sporangia far from the strobilus axis (fig. $2 d$, upper black arrowhead; fig. $4 a$, upper arrowhead). Mostly the base and apex are tapering, but specimens very close to the axis usually have a wide base and a tapering apex. In good specimens, certain compressions may be preserved with a transverse section of a sporangium, so that the spores are visible (fig. $4 c-4 g$ ). Judging from the areas where the sporangia can be counted and from the sizes of these areas in relation to the total areas of the disks, there are probably $80-90$ sporangia attached to each disk. For instance, there are ca. 42 sporangia counted on about half a disk of sporophylls (fig. 2a, lower right arrowhead), whereas there are ca. 22 sporangia counted on about one quarter-disk of sporophylls (fig. 2a, upper right arrowhead).

Maceration of coaly substances removed from the strobilus at the supposed position of sporangia did not yield any results. However, in situ spores are recognizable in broken sporangia under the stereomicroscope (fig. $4 c-4 g$ ). The spores are still in tetrads and of the trilete type, ranging between $30-80 \mu \mathrm{m}$ in diameter.

Comparison. Twenty-three species of Discinites have been described so far from the Carboniferous and Permian of Europe, North America, China, and Saudi Arabia (table 1). Discinites baculiformis sp. nov. is more than $310 \mathrm{~mm}$ in length and $15-18 \mathrm{~mm}$ in width, more slender than all the 23 known species. The longest ones previously known are Discinites raconicensis (Bek and Šimůnek 2005), which is 210 $\mathrm{mm}$ in length. The thinnest one previously known is Discinites delectus (Arnold 1949), which is $17 \mathrm{~mm}$ wide, similar in width to the new species. In terms of the length-to-width ratio, $D$. baculiformis sp. nov. is more than three times slenderer than $D$. delectus. Moreover, the number of sporangia bearing on each sporophyll disk in $D$. delectus is ca. 60, whereas it is $80-90$ in the new species. In D. baculiformis sp. nov., the total number of sporophyll disks on the strobilus is probably more than 78 . Such a quantity of sporophyll disks on a strobilus is significantly larger than those of previous described species of Discinites (table 1). Species for which the number of sporophyll disks has been estimated include D. hanchengensis, D. sinensis, Discinites bohemicus, D. egregius, D. hlizae, D. major, D. nemejcii, D. raconicensis, and D. cf. raconicensis. The sporophyll disk numbers of $D$. raconicensis and $D$. cf. raconicensis are the largest, ca. 26 , which is only one-third of that of the new species.

Discinites baculiformis sp. nov. is similar to D. sinensis Wang (2000) from the lower Permian of Shizuishan, Ningxia, with respect to strobilus diameter $(17$ and $20 \mathrm{~mm}$, respectively) and the distance (both are $4 \mathrm{~mm}$ ) between two adjacent disks of sporophylls, and the localities of the two species are in the same area (fig. 1). However, the sporangia of D. sinensis are much larger ( $4 \mathrm{~mm}$ long and $1.5 \mathrm{~mm}$ in diameter) than those of the new species $(2.5-3 \mathrm{~mm}$ long and $0.7-1.0$ $\mathrm{mm}$ in diameter), and the number of sporangia per disk of D. sinensis (30-35) is definitely much smaller than that of the new species (80-90). Additionally, the in situ spores of $D$. sinensis are of the Deltoidospora type, while those of $D$. baculiformis are only known to be of the trilete type. These differences are so significant that the fossil described here must be considered a new species.

Discinites dentilongus (Gao and Thomas 1994), from the early Permian of Taiyuan, resembles the new species in having the same number of similarly deep-toothed sporophylls, but differs from the new species in having considerably fewer and smaller sporangia per disk and wider, shorter strobili.

Discinites delectus, from the early Pennsylvanian of the Michigan coal basin (Arnold 1944, 1949), has approximately the same width of strobilus and distance between adjacent 

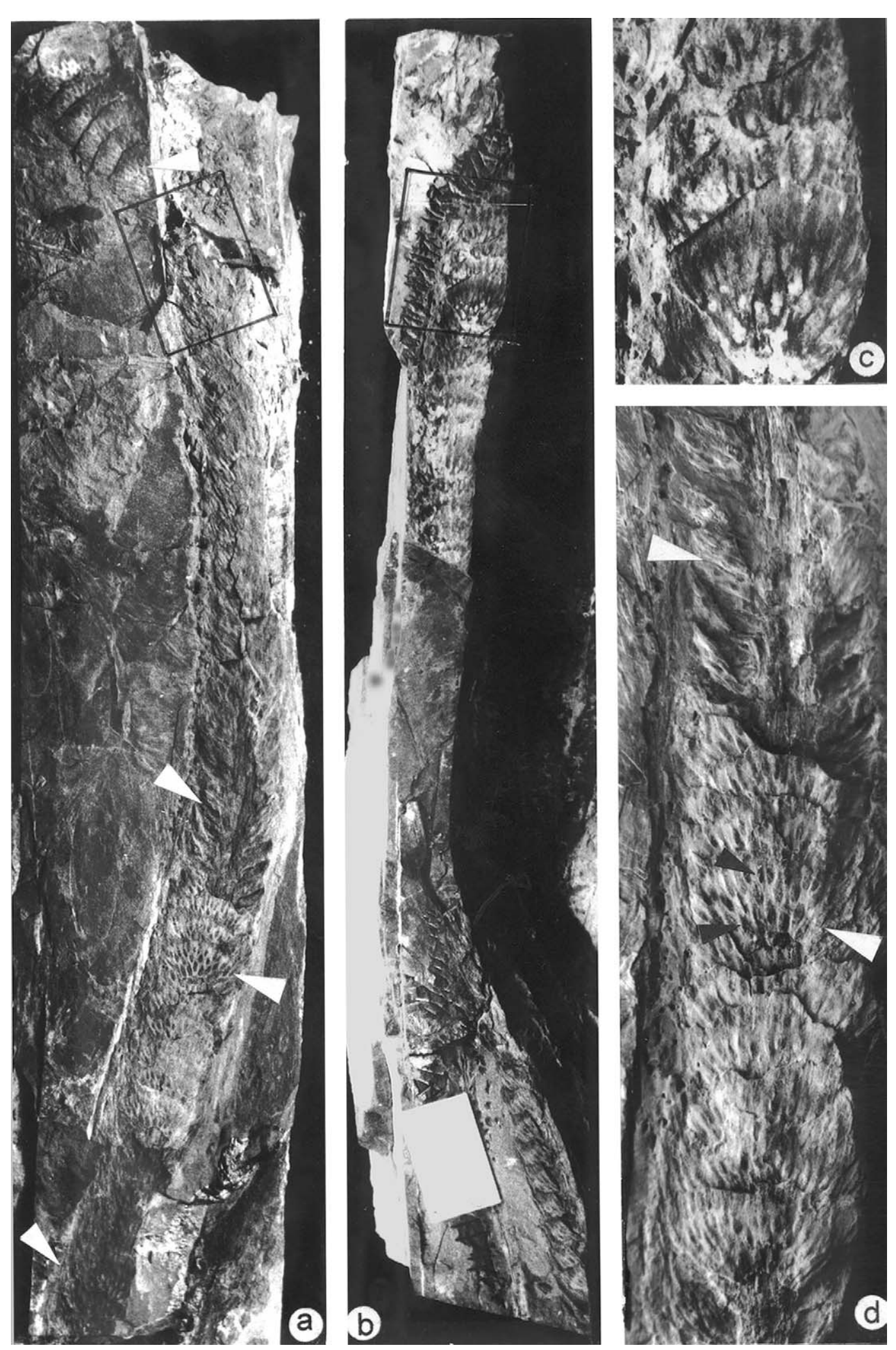

Fig. 2 General morphology of Discinites baculiformis sp. nov. $a, b$, Part and counterpart of the holotype. The frame in $a$ indicates an area where the connection between the upper and lower parts of the strobilus is not clearly shown, but it is reliably demonstrated in the counterpart specimen $b$ (within the frame). In $a$, the lower left arrowhead indicates an area where the apical teeth of sporophylls are not well exposed but are visible after the matrix is removed, as shown in fig. $3 b$; the lower right arrowhead indicates an area where half of a sporophyll disk is well exposed, 
disks of sporophylls as the new species, and so it appears similar in gross morphology, excluding the shorter length of the strobilus, which might be due to preservation. It differs from $D$. baculiformis sp. nov. in that the diameter $(1.7 \mathrm{~mm})$ of its sporangia is much larger than that of the new species $(0.7-1.0 \mathrm{~mm})$, and its sporangial number per disk (ca. 60) is much less than that of the new species (80-90).

Genus_-Yuania Sze, emend. Du and Zhu 1982

Species_Yuania wudensis Wang, Pfefferkorn, Feng and Shen sp. nov.

Syntypes. PB20259-20271 (figs. 5a-5b, 6b-6d, 7a).

Repository. Nanjing Institute of Geology and Palaeontology, Chinese Academy of Sciences, Nanjing 210008, China.

Type locality. Wuda, Inner Mongolia, China.

Stratigraphic position. Shanxi Formation.

Age. Early Permian (Asselian to Sakmarian).

Etymology. The species is named after the city of Wuda.

Diagnosis. Rachis unbranched, $4.0-8.3 \mathrm{~mm}$ wide and tapering gently upward to $1.0 \mathrm{~mm}$ or less in width. Pinnules alternate to subopposite and decurrent, with broad, obliquely clasping base. Pinnule insertion on rachis distant from each other (15 $\mathrm{mm}$ apart) to crowded, most crowded terminally; angles of pinnules insertion acute, ca. $45^{\circ}-90^{\circ}$, decreasing toward frond apex. Pinnules linear to oblong, 10-45 mm long and 2.5-17 mm wide, about two to four times as long as they are wide, with the proportionately widest pinnules occurring at frond bases; pinnule tips slightly wider than bases. Pinnules overlapping or separate. Veins dense and slender, with those in the base of pinnules slightly thicker; 12-20 veins entering pinnule bases, approximately half dichotomizing within basal one-third of lamina, some dichotomizing a second time. Twenty-five to 30 veins per pinnule counted at widest part of lamina, evenly spaced, converging toward pinnule apices. Epidermal cells rectangular, 25-40 $\mu \mathrm{m}$ wide and 40-140 $\mu \mathrm{m}$ long. No stomata detected.

Description. Specimens of Yuania have been regarded as either pinnate fronds (Mamay 1968; Du and Zhu 1982) or shoots with leaves arranged in flat planes (Gu and Zhi 1974; Wang and Wang 1987). The present authors use the terminology of Du and Zhu (1982) and Mamay (1968), which accords with the latest description of Noeggerathia (Šimůnek and Bek 2003), which is the representative member of the Noeggerathiales.

There are a larger number of fragments with pinnules attached. Twelve of them are selected as syntypes. The rachial fragment shown on figure $5 h$ is $20 \mathrm{~cm}$ long, with a greatest width of $5 \mathrm{~cm}$ at the upper part of the frond. The axis is ca. $5 \mathrm{~mm}$ wide at the basal part and gradually becomes more slender apically. The basal pinnules are ca. $12 \mathrm{~mm}$ wide and $24 \mathrm{~mm}$ long, and the apical pinnules are ca. $12 \mathrm{~mm}$ wide and $33 \mathrm{~mm}$ long. They are about two to three times as long as they are wide, and become wider basally. The frond tips each consist of an axis less than $1 \mathrm{~mm}$ wide and have very crowded pinnules that obviously terminate the frond (figs. $5 a, 6 c)$. The pinnules are narrow and long, about four times as long as they are wide, decreasing rapidly in size toward the apex. Figures $5 d, 6 a$, and $6 b$ represent the basal part of the fronds, each of which has an extremely sturdy axis compared to the size of the attached pinnules. Most of the pinnules are wide and short, about two to three times as long as they are wide. They are separated by a distance of ca. 12-14 $\mathrm{mm}$ on the rachis. In particular, the frond in figure $6 a, 6 b$ has a long pedicel at the base, on which no pinnules are detected. Rachial fragments, as shown in figure $5 b, 5 c$, with a ratio of length to width intermediate between these two extremes, are abundant, with a width of $10-16 \mathrm{~mm}$ being predominant. They probably represent the middle part of the frond. Figure $5 c$ may be a fragment from the very middle part of the frond, with pinnules evenly arranged and their form and size even, too. Figure $5 b$ may be a fragment of the middle upper part of the frond; the pinnules are more crowded, proportionately narrower and longer apically, and the size decreases apically.

Regardless of the position on the rachis, the lateral margins of the pinnules are always entire, curving gently and equally from the base to the tip. They are basally very broad and attached to the rachis in an obliquely clasping manner. Pinnule sizes range from 12 to $50 \mathrm{~mm}$ in length and 3.5 to $16 \mathrm{~mm}$ in width, are generally widest in the middle, and have a length-to-width ratio between $2: 1$ and $4: 1$.

The apices of pinnules are universally truncated (figs. $5 e-$ $5 g, 6 d)$. This is the most characteristic morphological feature of the pinnule. The truncated pinnule apices are slightly concave, with the truncated margin virtually perpendicular to the long axes of the pinnules. The width of the apex is slightly larger than half the width of the pinnule at the basal part of the frond, but gradually decreases upward to only one-half to one-third of the pinnule width at the middle upper part of the frond. Occasionally, several pinnules show lobed apical margins (fig. $5 c$, arrowhead), but this is probably a result of preservation, because all other pinnules are apically truncated.

The pinnules are inserted alternately (fig. $5 c$ ). In some specimens where the pinnules are close together (fig. $5 b, 5 b)$, it appears that some pinnules have a subopposite arrangement, but there is no evidence of clearly opposite foliation. The angles of pinnule insertion are ca. $70^{\circ}$ at the middle part of the frond, decreasing toward the frond apex to ca. $45^{\circ}$

so that the number of sporangia may be counted, and it is shown that the sporangia close to the axis of the strobilus are more highly compressed, appearing relatively larger in size than those far from the axis, which are only slightly compressed and appear small in size; the upper left arrowhead indicates an area where the connection of a sporophyll with the axis of the strobilus is clearly shown; the upper right arrowhead indicates a one-fourth part of sporophyll disk that is well preserved with the sporangia countable. $\times 0.8 ; a$, PB20252a; $b$, PB20252b. $c$, Partial enlargement of the area within the frame of the counterpart shown in $b$, showing the typical sporangial arrangement of Discinites. $\times 3$; PB20252b. $d$, Partial enlargement of the middle lower part of the holotype in $a$, showing the typical sporangial arrangement of Discinites. White arrowheads correspond, respectively, to the lower right and upper left arrowheads in $a$. The sporangium close to the axis (lower black arrowhead) is a little larger than the one far from the axis (upper black arrowhead). $\times 2$; PB20252a. 

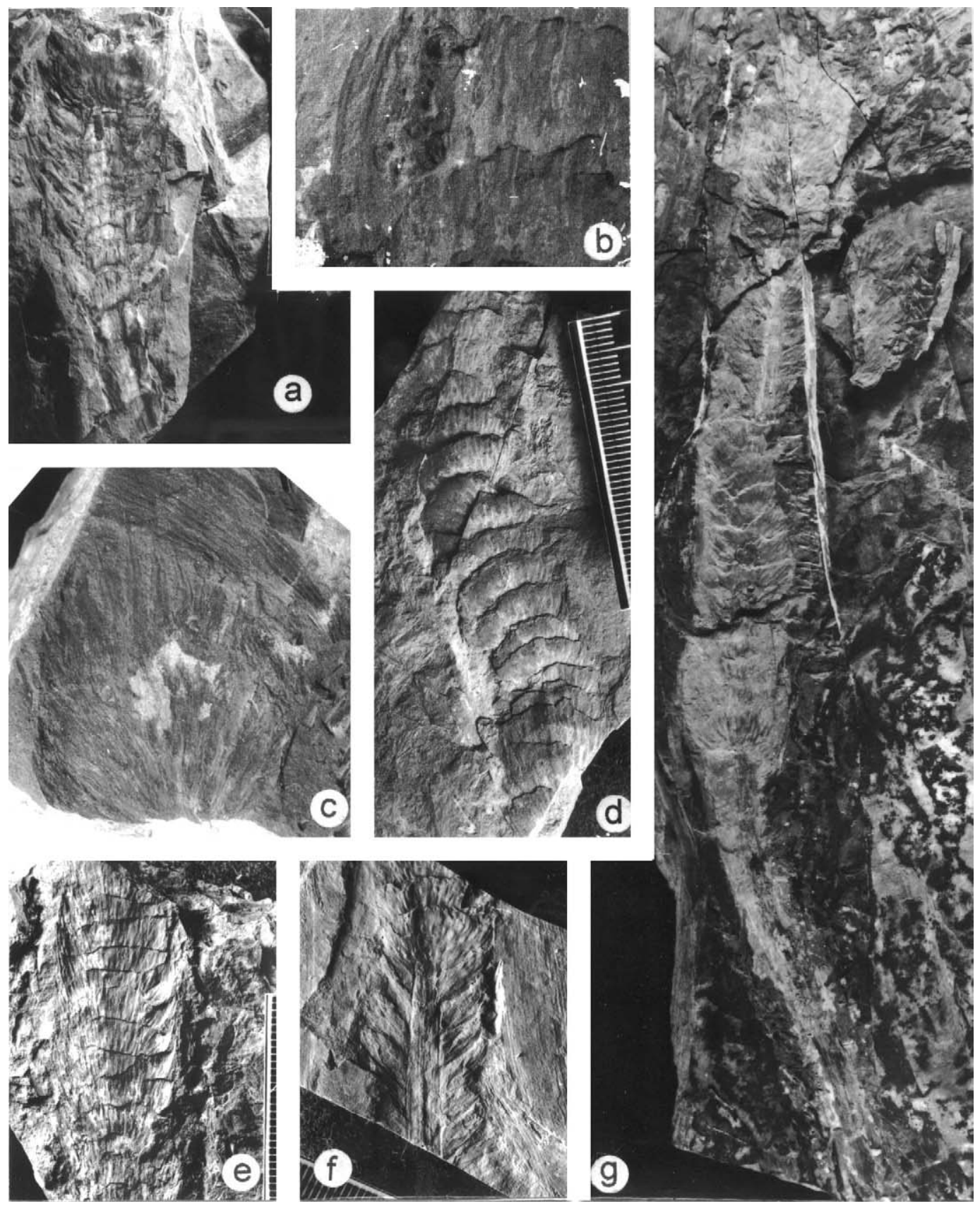

Fig. 3 General morphology of the strobilus. $a$, Specimen with the fracture pathway passing through the axis of the strobilus in the lower part and through the edge of the sporophyll disk in the upper part. The connection of sporophylls with the axis is clearly visible. $\times 1$; PB20253. $b$, Apical teeth of sporophylls of the holotype at the lower left arrowhead in fig. $2 a$ are well exposed after the matrix is detached. $\times 8$; PB20252a. $c$, Isolated sporophyll disk fragment showing that there is a single vein in the apical teeth of the sporophylls. $\times 2$; PB20254. $d$, Articulate character of the strobilus. The apical teeth of sporophylls are not preserved. $\times 1$; PB20255. e, Specimen with the fracture pathway passing through the apical teeth of sporophylls, which always extend upward and cover the upper neighboring sporophylls. $\times 1$; PB20256. $f$, Specimen with the fracture pathway passing through the axis in the lower part and the surface of the strobilus at the uppermost part. $\times 1$; PB20257. $g$, Strobilus with the basal long stalk preserved. $\times 0.7$; PB20258.

and increasing toward the base to $90^{\circ}$ (fig. $6 a, 6 b$ ). Pinnules are widely spaced at the base of the frond (fig. $5 d$; fig. $6 a, 6 b)$ and become crowded, so as to overlap each other and form an imbricate arrangement at the middle and upper part of the frond (fig. $5 a-5 c, 5 b$ ).
The venation of the pinnules consists of closely set parallel veins (figs. $5 a-5 e, 6 d$ ). There are $12-20$ veins entering the base of the lamina. Some of them divide equally in the proximal half of the lamina (fig. $5 c-5 d$ ) and then persist, evenly spaced, extending to the truncated apical margin, where they 

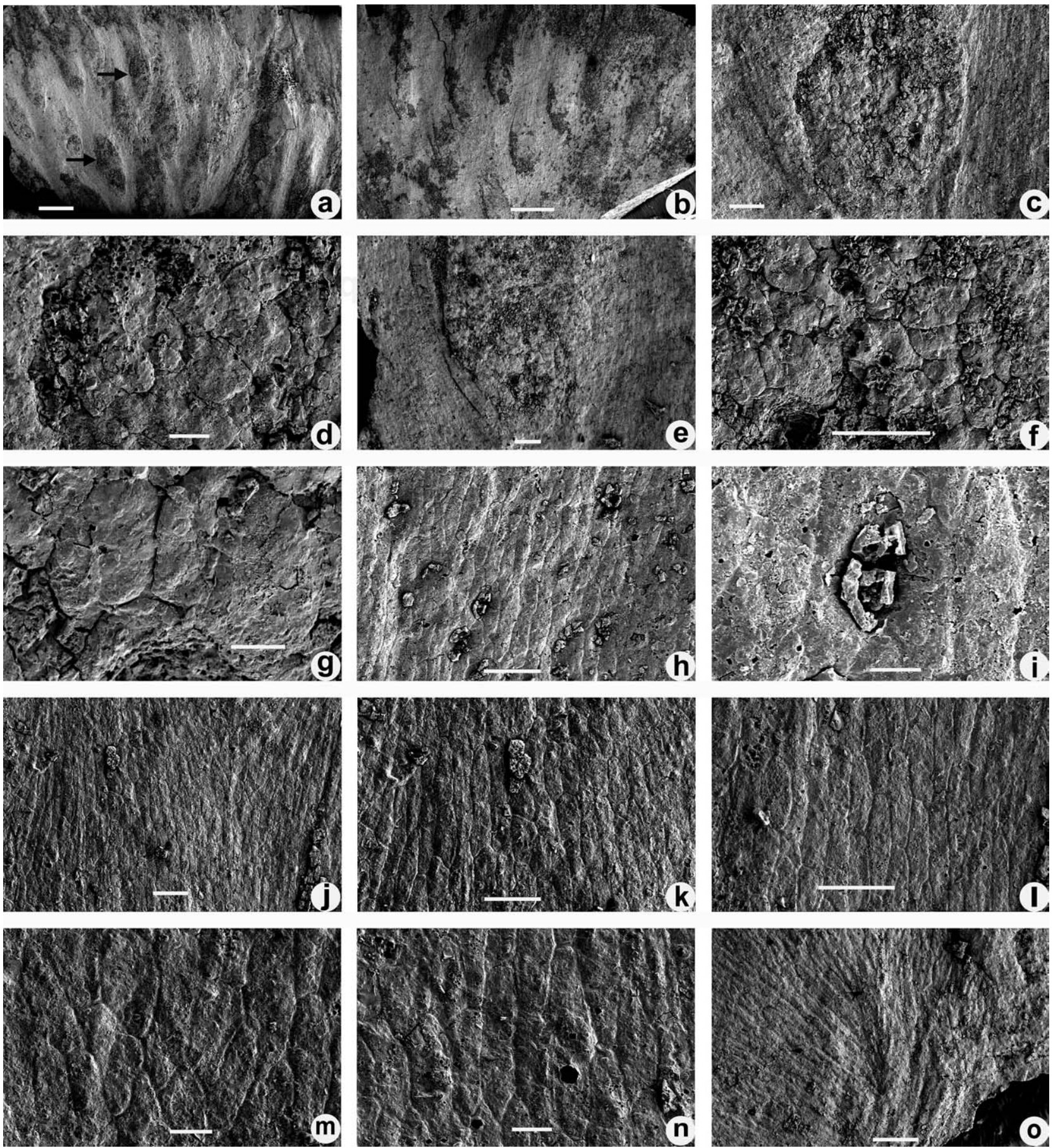

Fig. 4 General morphology of sporangia, in situ spores, and cells of sporophylls; all images are from holotype PB20252a. $a$, $b$, Pieces of sporophyll disks, showing sporangial forms and arrangement; scale bar $=1 \mathrm{~mm}$. $c-g$, Enlargements showing forms of sporangia and in situ spores; $c$, transverse section of a sporangium; scale bar $=30 \mu \mathrm{m} ; d$, enlargement of $c$, showing the in situ spores; scale bar $=100 \mu \mathrm{m}$; $e$, a sporangium, showing that the sporophyll cells laterally beside the sporangium are arranged with their longer axes parallel to the radial direction of the sporophyll disk; scale bar $=100 \mu \mathrm{m} ; f$, enlargement of $e$, showing the compressed in situ spores apparent in tetrads; scale bar $=100 \mu \mathrm{m}$; $g$, enlargement of $f$, showing a spore tetrad; scale bar $=20 \mu \mathrm{m} . h$, Enlargement of $a$, showing the cells on a sporophyll. There are two areas with stomata-like cell arrangements; scale bar $=100 \mu \mathrm{m}$. $i$, Enlargement of $h$, showing an area with a stomata-like cell arrangement; scale bar $=20$ $\mu \mathrm{m}$. $j$, Enlargement of $b$, showing the cell forms on sporophylls; scale bar $=100 \mu \mathrm{m} . k-n$, Further enlargements of $j$, showing the cell morphology of sporophyll; scale bar in $k, l=100 \mu \mathrm{m}$; scale bar in $m, n=30 \mu \mathrm{m}$. $o$, Piece of sporophyll disk with the base connected with the axis of strobilus, showing that the cells of sporophylls are arranged with their long axes in the radial direction of the sporophyll disk; scale bar $=200 \mu \mathrm{m}$. 
Table 1

Comparison among Discinites baculiformis sp. nov. and Other Discinites Species

\begin{tabular}{|c|c|c|c|c|c|c|c|c|c|c|c|c|c|c|c|c|c|c|}
\hline \multirow[b]{3}{*}{ Species } & & & \multicolumn{5}{|c|}{ Sporophylls } & \multicolumn{5}{|c|}{ Sporangia } & \multirow{3}{*}{$\begin{array}{l}\text { Output, } \\
\text { macro- } \\
\text { sporangia/ } \\
\text { micro- } \\
\text { sporangia }\end{array}$} & \multirow{2}{*}{\multicolumn{3}{|c|}{ Spores }} & \multirow[b]{3}{*}{ Age } & \multirow[b]{3}{*}{ Locality } \\
\hline & \multicolumn{2}{|c|}{ Strobilus } & \multirow{2}{*}{$\begin{array}{l}\text { Axis } \\
\text { width } \\
(\mathrm{mm})\end{array}$} & \multirow[b]{2}{*}{ Whorls } & \multirow{2}{*}{$\begin{array}{c}\text { Distance } \\
\text { between } \\
\text { whorls } \\
(\mathrm{mm})\end{array}$} & \multicolumn{2}{|c|}{ Teeth } & \multirow[b]{2}{*}{$\begin{array}{l}\text { Cuticular } \\
\text { cell }\end{array}$} & \multirow[b]{2}{*}{ Arrangement } & \multicolumn{2}{|c|}{ Size } & \multirow[b]{2}{*}{$\begin{array}{l}\text { No. per } \\
\text { Disk }\end{array}$} & & & & & & \\
\hline & $\begin{array}{c}\text { Length } \\
(\mathrm{mm})\end{array}$ & $\begin{array}{l}\text { Width } \\
(\mathrm{mm})\end{array}$ & & & & No. & $\begin{array}{l}\text { Length } \\
(\mathrm{mm})\end{array}$ & & & $\begin{array}{l}\text { Large } \\
(\mathrm{mm})\end{array}$ & $\begin{array}{l}\text { Small } \\
(\mathrm{mm})\end{array}$ & & & $\begin{array}{c}\text { Macrospore } \\
\text { size }(\mu \mathrm{m})\end{array}$ & $\begin{array}{c}\text { Microspore } \\
\text { size }(\mu \mathrm{m})\end{array}$ & Type & & \\
\hline D. baculiformis sp. nov. & 310 & $15-18$ & 3.5 & 78 & 4 & 50 & 8 & Elongate & Radiate & $2.5-3$ & $0.7-1$ & $80-90$ & & & & & & \\
\hline $\begin{array}{l}\text { D. hanchengensis (Wang } \\
\text { and Shen 2000) }\end{array}$ & $90-110$ & $30-50$ & $6-10$ & 20 & $3-6$ & $25-40$ & $6-9$ & Elongate & Radiate & 2 & 1 & $\begin{array}{r}100,5-6 \\
\text { circles }\end{array}$ & $16 \% /$ & $300-380$ & $45-90$ & $\begin{array}{l}\text { Calamospora } \\
\text { (Punctatisporites)/ } \\
\text { Calamospora } \\
\text { (Cyclogranisporites) }\end{array}$ & $\mathrm{P}_{2}$ & China \\
\hline $\begin{array}{l}\text { D. sinensis (Wang 2000) } \\
\text { D. dentilongus (Gao and }\end{array}$ & 20 & 20 & 5.7 & 5 & 4 & & & Elongate & Radiate & 4 & 1.5 & $30-35$ & $>100 />1000$ & $150-180$ & $70-120$ & Deltoidospora & $P_{1}$ & China \\
\hline $\begin{array}{l}\text { Thomas 1994) } \\
\text { D. bohemicus (Feistmantel }\end{array}$ & 64 & 25 & 5 & & 4 & 50 & 13 & Elongate & Radiate & 1.25 & 0.6 & 50 & & & & & $\mathrm{P}_{1}$ & China \\
\hline 1880) & 100 & $22-25$ & $3-4$ & 25 & $3-4$ & & & & & $2.5-5$ & $1.2-2$ & $100-150$ & & & & & $\mathrm{C}_{2}$ & $\begin{array}{l}\text { Czech } \\
\text { Republic, } \\
\text { Belgium }\end{array}$ \\
\hline $\begin{array}{l}\text { D. cf. bohemicus (Remy } \\
\text { and Remy 1956) }\end{array}$ & 75 & 25 & & & & & & & & 2.5 & 2 & & $16 \% / \ldots$ & $550-640$ & $54-94$ & Punctatisporites & $\mathrm{C}_{2}$ & $\begin{array}{l}\text { Czech } \\
\text { Republic }\end{array}$ \\
\hline $\begin{array}{l}\text { D. delectus (Arnold 1944, } \\
\text { 1949) }\end{array}$ & 100 & 17 & & & 5 & & & & pairs & 2.5 & 1.7 & 60 & $16 ? / \ldots$ & $600-750$ & $75-90$ & Calamospora & $\mathrm{C}_{2}$ & U.S.A. \\
\hline D. egregius (Boureau 1964) & 95 & 30 & 8 & 13 & & & & & & & & & $16 / \ldots$ & & & & $\mathrm{C}_{2}$ & France \\
\hline D. hlizae (Němejc 1941) & $80-115$ & $30-40$ & & 16 & $4-5$ & & & & & $2-2.5$ & $1.4-2$ & $700 ?$ & & $500-770$ & $60-100$ & Calamospora & $\mathrm{C}_{2}$ & $\begin{array}{l}\text { Czech } \\
\text { Republic }\end{array}$ \\
\hline $\begin{array}{l}\text { D. jongmansi (Hirmer and } \\
\text { Guthörl 1940) }\end{array}$ & 95 & 18 & 4 & & & & & 6-7 & & 2.5 & 1.5 & & & & & & $\mathrm{C}_{2}$ & $\begin{array}{l}\text { U.S.A., } \\
\text { Netherlands }\end{array}$ \\
\hline D. major (Němejc 1937) & 90 & $30-35$ & $3-4$ & 18 & $4-5$ & & & & & $2.8-3.8$ & $1.3-2$ & $170-200$ & $1 / \ldots$ & $1000-1300$ & $95-115$ & & $\mathrm{C}_{2}$ & $\begin{array}{l}\text { Czech } \\
\text { Republic }\end{array}$ \\
\hline $\begin{array}{l}\text { D. raconicensis (Němejc } \\
\text { 1941) }\end{array}$ & 210 & 46 & & 26 & $\begin{array}{l}5 \text { (near the } \\
\quad \text { apex), } 8-11\end{array}$ & & & & Radiate & $2.5-5$ & $2-2.5$ & Hundreds & & & & & $\mathrm{C}_{2}$ & $\begin{array}{l}\text { Czech } \\
\text { Republic }\end{array}$ \\
\hline $\begin{array}{l}\text { D. cf. raconicensis (Bek and } \\
\text { Šmünek 2004) } \\
\text { D. orientalis (Gu and Zhi }\end{array}$ & 160 & $60-70(45)$ & & 26 & $5-7$ & & & & & $2.4-4$ & $1.2-2.2$ & $900-1400$ & & & & & & \\
\hline 1974) & & 20 & $6-7$ & & 3 & Serrated & & & Radiate & 3.5 & 1.5 & 7 circles & & & & & $\mathrm{P}$ & $\begin{array}{l}\text { China, } \\
\text { Saudi } \\
\text { Arabia }\end{array}$ \\
\hline $\begin{array}{l}\text { D. cf. orientalis (Zhao } \\
\text { et. al. 1980) } \\
\text { D. sp. (Remy and Remy }\end{array}$ & & 28 & 3.5 & & & & & & Radiate & & & & & & & & $\mathrm{P}_{2}$ & China \\
\hline 1956) & 48 & 18 & & & & & & & & & & & & & $85-130$ & Calamospora & $\mathrm{C}_{2}$ & Germany \\
\hline D. sp. (Mamay 1954) & 45 & 25 & 4 & & & $40-50$ & $4-6$ & & radiate & $0.7-1$ & & $\begin{array}{l}4-5 \text { circles } \\
(100-150)\end{array}$ & & & & & $\mathrm{P}_{1}$ & U.S.A. \\
\hline $\begin{array}{l}\text { D. nemejcii (Bek and } \\
\text { Šimůnek 2005) }\end{array}$ & 92 & $30-38$ & $2-3 ?$ & $>23$ & 4 & & & & & $1.5-2.5$ & $1-1.8$ & $250-700 ?$ & $16 / \ldots$ & $305-680$ & $60-87$ & & C & $\begin{array}{l}\text { Czech } \\
\text { Republic }\end{array}$ \\
\hline D. sp. 2 (Němejc 1941) & & & & & & & & & & & & & & & & & $\mathrm{C}_{2}$ & $\begin{array}{l}\text { Czech } \\
\text { Republic }\end{array}$ \\
\hline D. sp. (Potonié 1965) & & & & & & & & & & & & & & & & Laevigatosporites & C & U.S.A. \\
\hline D. sp. (Mei et. al. 1996) & & & & & & & & & & & & & & & & & $P_{1}$ & China \\
\hline D. sp. (Liu and Shen 1978) & & & & $2-3$ & & & & & Radiate & & & & & & & & $\mathrm{P}_{1}$ & China \\
\hline D. sp. (Bohlin 1971) & & 20 & & & & $20-30$ & & & Radiate & 2.8 & 1.5 & 3-4 circles & & & & & C-P & China \\
\hline
\end{tabular}

$\mathrm{C}=$ Carboniferous; $\mathrm{C}_{2}=$ Late Carboniferous. Measurements are based on the preserved parts of the strobili, and consequently the true dimensions/quantities should be larger than the results of the current calculation. 

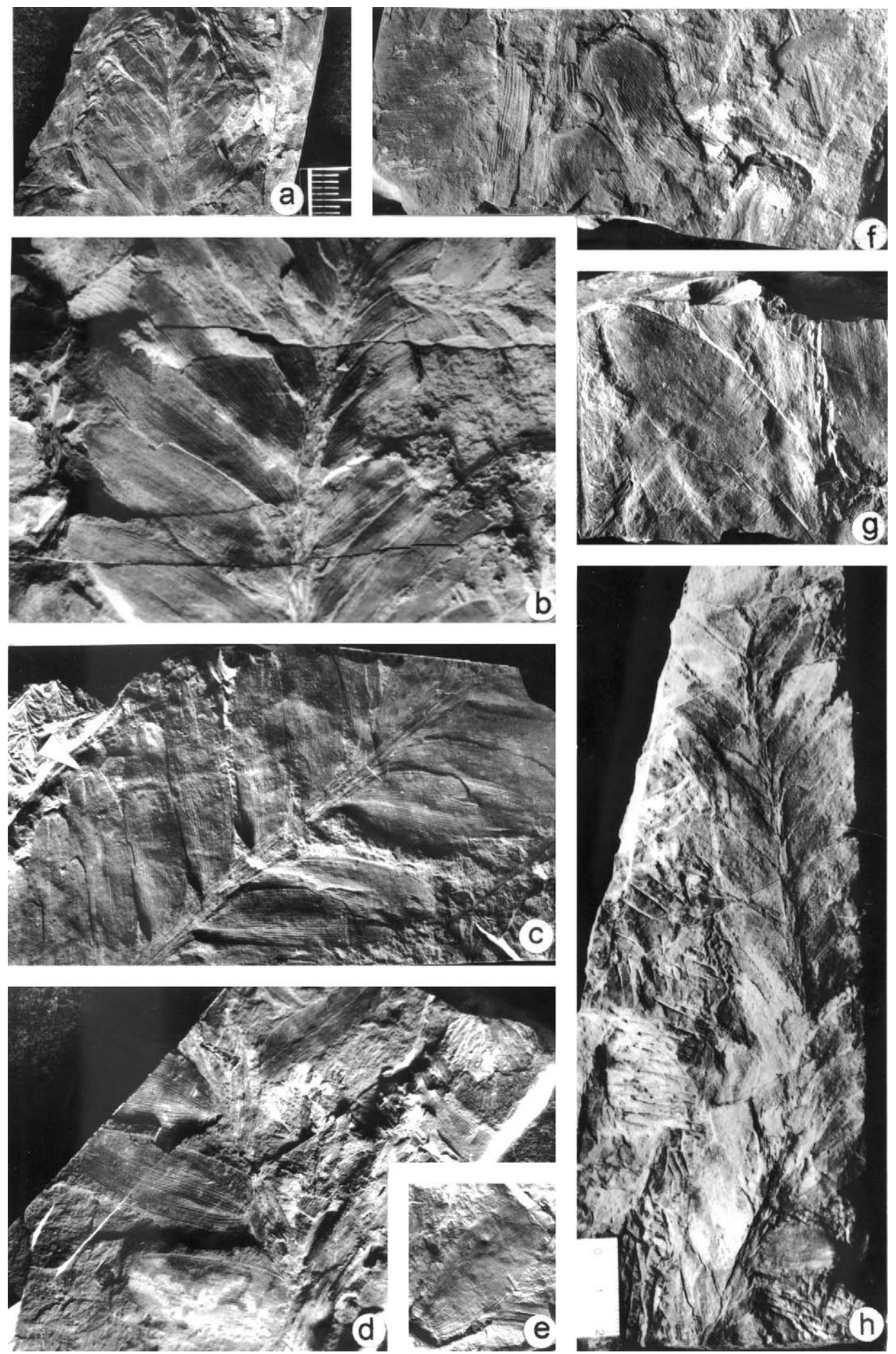

Fig. 5 General morphology of Yuania wudensis sp. nov. $a-d$, Fragmentary fronds showing, respectively, the apical (a), middle upper (b), middle $(c)$, and basal $(d)$ parts, with their pinnules varying in terms of the shape, size, ratio of length to width, density of arrangement, and thickness of the rachis. $\times 1$; $a$, PB20259; $b$, PB20260; $c$, PB20261; $d$, PB20262. $e-g$, General form, especially the truncate apices. $\times 1 ; e, \mathrm{~PB} 20263$; $f$, PB20264; $g$, PB20265. $h$, Fragmentary specimen representing a frond from the lower to middle upper part. $\times 0.7$; PB20266. 

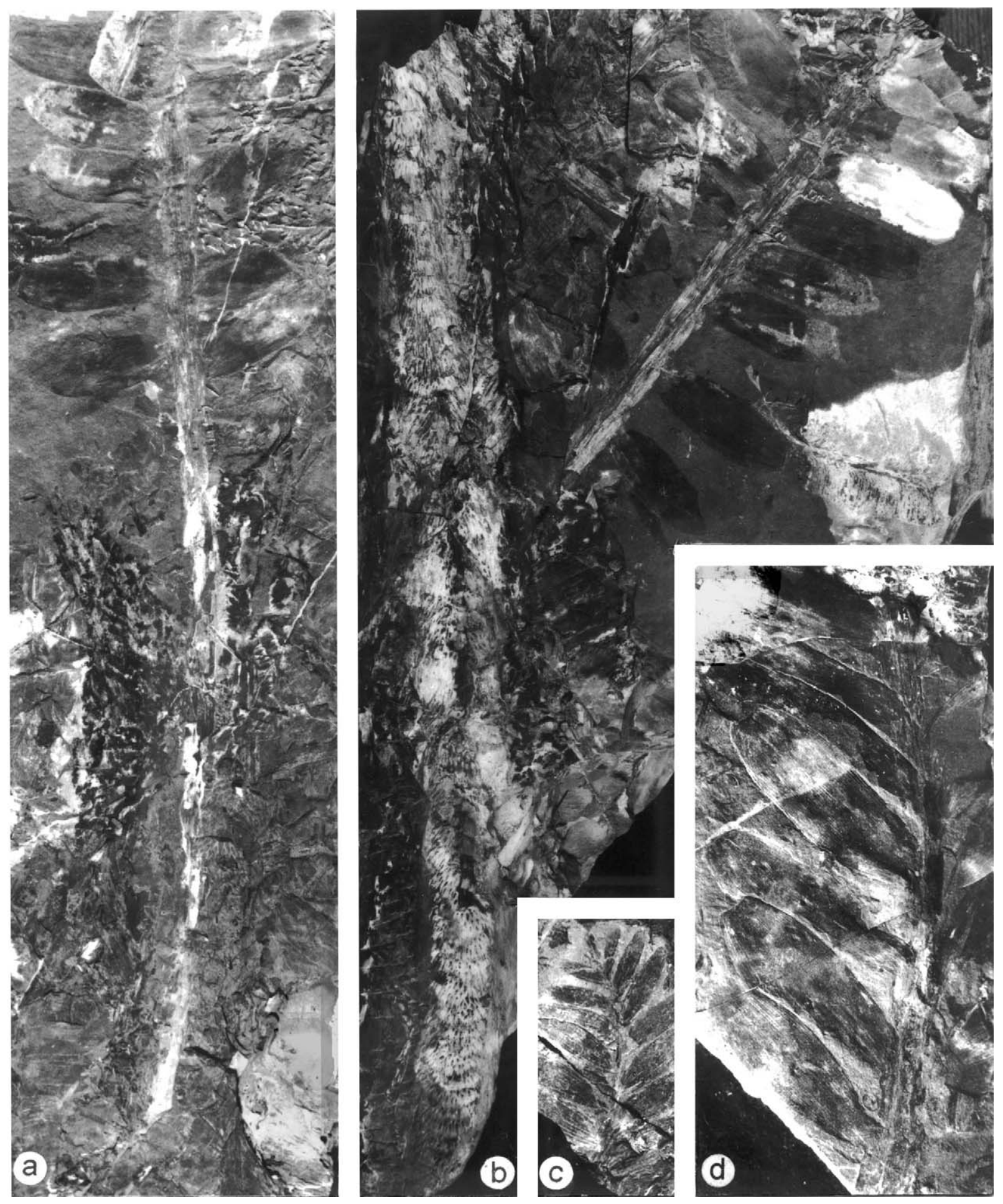

Fig. 6 General morphology of Yuania wudensis sp. nov. and Discinites baculiformis sp. nov. a, Basal part of a frond, showing the morphology of basal pinnules. $\times 0.6$; PB20267. $b$, A strobilus (on the left), incomplete at the base and the apex, with a length of $31 \mathrm{~cm}$ and a width of $1.8 \mathrm{~cm}$ at the lower part and $1.5 \mathrm{~cm}$ at the upper part. The frond at the upper right is the counterpart of the upper part of the specimen in $a$. $\times 0.6$; PB20268. $c$, Morphology of the pinnules at the apex. $\times 1.1$; PB20269. $d$, Morphology of the pinnules at the middle part of a frond. $\times 1.05$; PB20270. 
converge toward each other as the lamina decreases in width. In the distal half of the lamina (figs. $5 d-5 f, 7 a$ ), where the veins usually do not divide further, there are ca. 25-30 veins, while in some wider lamina the number of veins may reach 35 (fig. $5 \mathrm{~g}$ ).

The outline of epidermal cells is clearly recognizable under the stereomicroscope (fig. $7 a, 7 b$ ) and with the SEM (fig. $7 c-$ $7 b)$. Epidermal cells are generally rectangular in outline, sometimes with ends pointed, 18-42 $\mu \mathrm{m}$ in width and 40$118 \mu \mathrm{m}$ in length, mostly ca. $30 \mu \mathrm{m}$ wide and $50-80 \mu \mathrm{m}$ long. Occasionally, cells $150 \mu \mathrm{m}$ long can be recognized (fig. $7 d)$. They are arranged with the long sides parallel to the veins. No stomata were detected in a more than $3-\mathrm{cm}^{2}$ lamina impression.

Comparison. Yuania wudensis sp. nov. demonstrates for the first time the forms of epidermal cells of Yuania, al- though the outlines of epidermal cells are only revealed by their impressions rather than their true cuticles. In terms of the average pinnule size, Yuania wudensis sp. nov. may be the second smallest among known species of Yuania (table 2), with the generic type species Yuania striata Sze the smallest.

The pinnule characteristics of Yuania gigantea (Zhu and $\mathrm{Hu}$ 1982) all fall within the ranges of the new species (table 2). However, Y. gigantea is actually only defined according to the basal part of the frond (pl. 1, fig. 6 of $\mathrm{Zhu}$ and $\mathrm{Hu}$ 1982). The pinnules of Y. gigantea are only comparable with, but much larger than, those of the basal part of Y. wudensis sp. nov. Moreover, the pinnules of Y. gigantea are definitely decurrent. Such a characteristic is not as obvious in the pinnules of the new species, especially in the pinnules at the basal part of the frond (fig. $5 d, 5 e$; fig. $6 a, 6 b$ ).
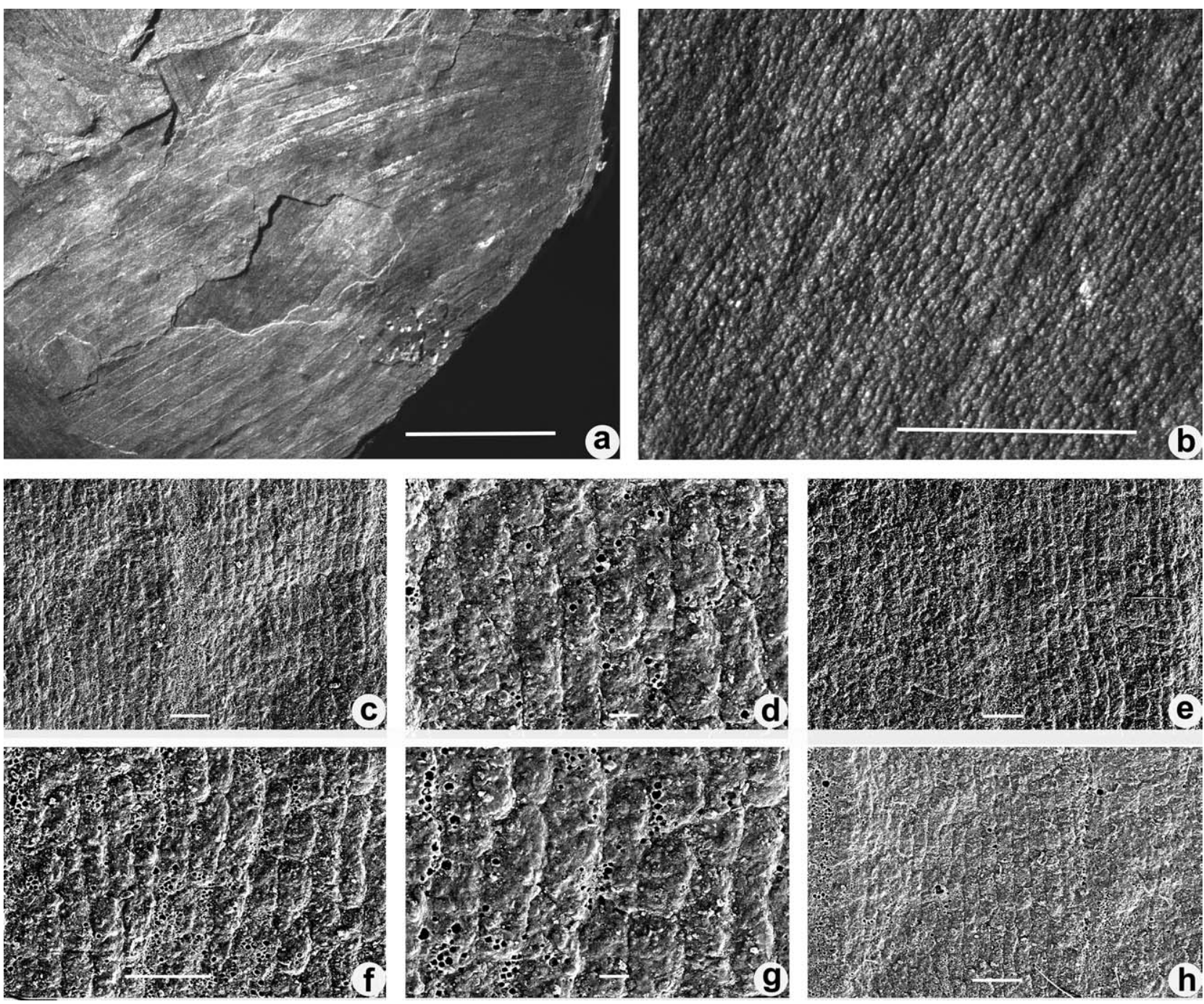

Fig. 7 Cell morphology of the pinnules of Yuania wudensis sp. nov. All images are from specimen PB20271. $a$, A piece of pinnule with the impression of cells well preserved; scale bar $=5 \mathrm{~mm} ; b-h$, Enlargements of the pinnule in $a$, showing cell morphology and arrangement. $b$, Photograph under stereomicroscope showing the parallel veins and the cells between them; scale bar $=2 \mathrm{~mm}$. $c-h$, SEM images with different degrees of enlargement, showing the cell morphology and arrangement; $c, e$, and $b$ show that epidermal cells are all longitudinally arranged along with the parallel veins; $d, f$, and $g$ show the variation in the length and width of cells. A cell could be much longer or wider than the neighboring ones. The scale bar in $c, e, f, b$ is $100 \mu \mathrm{m}$; that in $d$ and $g$ is $20 \mu \mathrm{m}$. 
Table 2

Comparison of Yuania wudensis sp. nov. with Other Species of Yuania and Russellites

\begin{tabular}{|c|c|c|c|c|c|c|c|}
\hline $\begin{array}{l}\text { Characteristics of } \\
\text { pinna }\end{array}$ & $\begin{array}{l}\text { Y. wudensis } \\
\text { sp. nov. }\end{array}$ & Y. striata & Y. chinensis & Y. gigantea & Y. longifolia & Y. magnifolia & $\begin{array}{l}\text { Russellites } \\
\text { taeniata }\end{array}$ \\
\hline Length of pinna (mm) & $12-50$ & 11 & $20-65$ & $40-45$ & 50 & $25-60$ & $20-115$ \\
\hline Length/width & $2-4$ & 2 & $1-4$ & $2-3$ & 4 & $4-5$ & $2-8$ \\
\hline No. of veins & $25-35$ & $<20$ & $20-30$ & 35 & $26-31$ & $20-30$ & $8-58$ \\
\hline Anastomosis of venation & None & None & None & None & Rare & None & Rare \\
\hline Leaf scale & & & Subulate & & & & \\
\hline Epidermal cell & $\begin{array}{l}\text { Enlongate/ } \\
\text { rectangular }\end{array}$ & & & & & & \\
\hline Reference & This article & Sze 1953 & $\begin{array}{c}\text { Du and Zhu } \\
1982\end{array}$ & $\begin{array}{l}\text { Zhu and } \mathrm{Hu} \\
1982\end{array}$ & Xiao 1985 & $\begin{array}{l}\text { Wang and Wang } \\
1987\end{array}$ & Mamay 1968 \\
\hline
\end{tabular}

Note. Russellites Mamay 1968 was regarded as a synonymy of Yuania (Sze) by Du and Zhu (1982), but this was rejected by Mamay (1995). Without a direct comparison based on the holotype specimens of the two genera, it might be better to let them coexist for the time being.

Yuania longifolia (Xiao 1985) somewhat resembles the new species in the middle upper part of the frond in gross morphology. However, an anastomosis of venation is detected in its laminae, and the basal and apical parts of the $Y$. longifolia frond are not known.

Yuania magnifolia (Wang and Wang 1987) is represented by the middle and apical frond. It differs from the new species in its larger pinnule size, the looser arrangement of pinnules, and the wider angle of insertion of pinnules to the rachis.

Yuania chinensis (Du and Zhu 1982) is also represented by a complete pinnate frond. It differs from the new species in that the pinnules of $Y$. chinensis are slightly narrower and longer than those at the corresponding locations in Y. wudensis sp. nov. Interestingly, Y. chinensis is the only species of Yuania whose base is completely preserved, indicating that leaf scales occur at the base of the frond.

$\mathrm{Du}$ and Zhu (1982) regarded Russellites taeniata (Mamay 1968), from the lower Permian of Texas, as a synonym of Yuania, but Mamay $(1990,1995)$ rejected this opinion. The generic synonymy will be addressed elsewhere, but a comparison of the species is of importance in this context. The American species has a much larger frond and larger pinnules, shows a very wide range in the density of venation, and its veins anastomose. Consequently, it can be easily distinguished from Y. wudensis sp. nov.

\section{Discussion}

Discinites is well known from the Carboniferous and Permian of Europe, North America, Saudi Arabia, and China. Various types of sterile foliage are considered to belong to Discinites (Šimůnek and Bek 2003). They include Russellites (Mamay 1968) and Eremopteris (Arnold 1949) from the U.S.A., Palaeopteridium (Němejc 1937), Saaropteris, and Rhacopteris (Němejc 1941) from Europe, and Tingia (T. carbonica type), Plagiozamites, and Yuania (Wang and Shen 2000) from China.

Yuania wudensis sp. nov. and Discinites baculiformis sp. nov. are closely associated and are dominant in the same taphoflora. Such an association may be significant because the other members in the community, including Taeniopteris,
Sphenopteris, Lepidodendron, Callipteris, and the seed Cornucarpus, are known to belong to lycopsids, cycads, ferns, or pteridosperms. Yuania and Discinites are, respectively, well known foliage and fructification of the Noeggerathiales, so that it is reasonable to deduce that Y. wudensis and Discinites baculiformis may be parts of the same plant. A precedent for this association is the close co-occurrence of the frond of Russelites with the fructification Discinites in the lower Permian of Texas (Mamay 1968). Whether or not Russellites is a synonym of Yuania (Du and Zhu 1982; Mamay 1990, 1995), they are very similar plants that certainly represent the same group. It is noteworthy that in the taphoflora from the lower Permian of Texas, Discinites and Russellites, respectively, represent the only noeggerathialean fructification and foliage, so that their association may be the same as the association of D. baculiformis sp. nov. and Y. wudensis sp. nov.

The epidermal cells of the sporophylls of D. baculiformis sp. nov. and the pinnules of $Y$. wudensis sp. nov. are similar in terms of their general form, size, and arrangement. Epidermal cells of both organs are rectangular and sometimes have pointed ends that are long and narrow. The abaxial surface of the sporophylls of $D$. baculiformis sp. nov. was carefully examined, but only two possible stomata were detected on an area of more than $150 \mathrm{~mm}^{2}$. Therefore, there might be very few or no stomata on the sporophylls of D. baculiformis sp. nov. Meanwhile, a number of fragments of Y. wudensis sp. nov. were examined, but unfortunately, no stomata were detected over an area of more than $300 \mathrm{~mm}^{2}$ of lamina. It could not be determined if the specimen represents the adaxial or abaxial surface of the lamina. It is unfortunate that the observed cell pattern of the sporophylls of D. baculiformis sp. nov. and the lamina of Y. wudensis sp. nov. did not show stomata, which might have aided in determining whether the two form species belong to the same natural species.

\section{Acknowledgments}

This study was funded by the National Natural Science Foundation of China (projects 40102002, 40321202) and KZCX2-SW-130, Chinese Academy of Sciences. We would like to acknowledge the State Key Laboratory of Paleobiol- 
ogy and the Nanjing Institute of Geology and Palaeontology for the use of LEO 1530VP, JSM-6300, and Leica DC300 to make SEM and stereomicroscope observations. We thank the reviewer for providing information on Discinites strobili in the Czech Republic and Barbara Pfefferkorn for editorial help.

\section{Literature Cited}

Arnold CA 1944 A heterosporous species of Bowmanites from the Michigan coal basin. Am J Bot 31:466-469.

1949 Fossil flora of the Michigan coal basin. Contrib Mus Paleontol Univ Mich 7:131-269.

Balme BE 1995 Fossil in situ spores and pollen grains: an annotated catalogue. Rev Palaeobot Palynol 87:81-323.

Bek J, Z Šimůnek 2005 Revision of Discinites from the Bohemian Carboniferous continental basins. Palaeontology (in press).

Bohlin B 1971 Late Palaeozoic plants from Yuerhhung, Kansu, China. The Sino-Swedish expedition, publication 51. Sven Hedin Foundation, Stockholm. 150 pp.

Boureau E 1964 Traité de paléobotanique. Vol 3. Sphenophyta and Noeggerathiophyta. Masson, Paris. 544 pp.

Du X, J Zhu 1982 The emendation of a cycad genus Yuania and the discovery of Y. Chinensis sp. nov. Mem Beijing Nat Hist Mus 17: 1-6. (In Chinese; English abstract.)

Feistmantel K 1880 Eine neue Pflanzengattung aus böhmischen Steinkohlenschichten. Sitzungsber Kon Bohm Ges Wiss 298-303.

Gao Z, BA Thomas 1994 A new species of Discinites from the Lower Permian of China. Rev Palaeobot Palynol 81:185-192.

Gothan W, H Weyland 1973 Lehrbuch der paläobotanik. Akademie, Berlin. 677 pp.

Gu and Zhi (Nanjing Institute of Geology and Palaeontology Institute of Botany Writing Group) 1974 Chinese plant fossils. Vol I. Palaeozoic plants from China. Science Press, Beijing. (In Chinese.) 277 pp.

Hill CR, AA El-Khayal 1983 Late Permian plants including Charophytes from the Khuff Formation of Saudi Arabia. Bull Br Mus (Nat Hist) Geol 37:105-112.

Hirmer M, P Guthörl 1940 Noeggerathiineae. Palaeontogr Suppl Bd 9:3-60.

Liu H, G Shen 1978 Carboniferous and Permian floras of the Longshou Mountains in Gan Su. LanZhou University, LanZhou. (In Chinese.)

Mamay SH 1954 A Permian Discinites cone. J Wash Acad Sci 44: 7-11.

1968 Russelites, new genus, a problematical plant from the lower Permian of Texas. U.S. Geological Survey Professional Paper 593-I. Washington, D.C.

1990 Charliea manzanitana, n. gen., n. sp., and other enigmatic parallel-veined foliar forms from the upper Pennsylvanian of New Mexico and Texas. Am J Bot 77:858-866.

1995 Reinstatement of the fossil name Russellites (not a synonym of Yuania). Taxon 44:43-51.

Mei M, Q Huang, M Du, DL Dilcher 1996 The Xu-Huai-Yu subprovince of the Cathaysian floral province. Rev Palaeobot Palynol 90:63-77.
Nermejc F 1931 The morphology and the systematic relations of the Carboniferous Noeggerathiae with regard to the "genera" Tingia and Plagiozamites of eastern Asia. Preslia 10:111-114.

$$
\text { 3-10. }
$$

1937 On Discinites K. Feistm. Bull Int Acad Sci Boheme 38: einigen Bemerkungen über die Archaeopteriden der Mittelböhmischen Kohlenbecken. Mitt Tschech Akad Wiss 19:1-13.

Potonié R 1965 Fossile sporae in situ. Forschungsber Landes Nordrhein-Westfalen 1483:1-74.

Remy W, R Remy 1956 Noeggerathiostrobus vicinalis E. Weiss und Bemerkungen zu ähnlichen Fruktifikationen. Abh Dtsch Akad Wiss Chem Geol Biol 2:1-11.

Šimůnek Z, J Bek 2003 Noeggerathiaceae from the Carboniferous basins of the Bohemian Massif. Rev Palaeobot Palynol 125: 249-284.

Sze C 1953 Notes on some fossil remains from the Shihchienfeng Series in northwestern Shensi. Acta Palaeontol Sin 1:11-22.

Taylor TN 1981 Palaeobotany: an introduction to fossil plant biology. McGraw-Hill, New York. 589 pp.

Wang J 2000 Discovery of a petrified Discinites (Noeggerathiales) cone from the Permian of Shizuishan, Ningxia, China: D. sinensis sp. nov. Chin Sci Bull 45:560-566.

Wang J, G Shen 2000 A new species of Discinites (Noeggerathiales) from the upper Permian of Weibei coalfield, North China. Rev Palaeobot Palynol 110:175-190.

Wang J, G Zhang, J Bek, HW Pfefferkorn 2004 A new morphological type of operculate microspore, Discinispora gen. nov., from the Permian petrified Noeggerathialean strobilus Discinites sinensis Wang. Rev Palaeobot Palynol 128:229-245.

Wang Z, L Wang 1987 Late Permian fossil plants from the lower part of the Shichienfeng Group in North China. Bull Tianjin Inst Geol Min Res 15:1-120. (In Chinese; English abstract.)

Xiao S 1985 Plant, Late Palaeozoic era. Page 549 in Tianjin Institute of Geology and Mineral Resources, ed. Paleontological atlas of North China. Vol I. Paleozoic. Geological Publishing House, Beijing.

Zhao X, Z Mo, S Zhang, Z Yao 1980 Late Permian flora from the west Guizhou and eastern Yunnan. Page 71 in Nanjing Institute of Geology and Palaeontology, Academia Sinica, ed. Late Permian coal-bearing stratigraphy and biota in west Guizhou and east Yunnan. Science Press, Beijing. (In Chinese.)

Zhu J, Y Hu 1982 Supplementary study of Upper Shihezi (Shihhotse) plants from Taiyuan, Shanxi Province. Acta Bot Sin 24:77-84. (In Chinese; English abstract.)

Zimmermann W 1959 Die Phylogenie der Pflanzen. 2d ed. Gustav Fischer, Stuttgart. 777 pp. 